\title{
Toll like receptors: an overview
}

\author{
Shah Gopi $\mathbf{H}^{1 *}$, Patel Bharat $\mathbf{G}^{2}$, Chorawala Mehul $\mathbf{R}^{3}$ \\ ${ }^{1}$ Ramanbhai Patel College of Pharmacy, department of Pharmacology Charusat Campus changa \\ ${ }^{2}$ Charotar University of Science \& Technology, Charusat Campus Changa \\ ${ }^{3}$ K.B.Institute of Pharmaceutical Education \& Research, Department of Pharmacology, \\ Sector-23, Gh-6 Corner, Gandhinagar-382023 \\ *Corresponding author E-mail: ghshah17213@gmail.com
}

\begin{abstract}
Toll like receptors (tlrs) are first identified in drosophila and recognise pathogen associated molecular patterns (pamps) expressed by various micro-organisms and are also known as pattern recognition receptors (prrs). pamps are important for both innate and adaptive response. Among all tlrs, tlr1, tlr2, tlr3 and tlr 4 are expressed on plasma membrane while tlr3, tlr $7, \operatorname{tr} 8$ and tlr 9 are expressed intracellularly. Downstream signalling of tlr activation involves expression of numerous cytokines, chemokines and co-stimulatory molecules such as irak, traf, tirap and sarm via myd88 dependant and independent pathway. This is a key step for both innate and adaptive immunity. tlrs play an important role in pathogenesis of various diseases including infectious diseases, autoimmune diseases, neurodegenerative diseases, lung disease, skin disease and cancer. Most studied tlrs are tlr2, tlr4, tlr3 and tlr9. In brief, this review emphasizes on types of tlr, their ligands, location, signalling pathway and role in various diseases.
\end{abstract}

Keywords: Toll like Receptors, Pathogen Molecular Patterns, Myd88 Pathway, Adaptor Proteins.

\section{Introduction}

The Toll like receptors are closely related to Toll is first identified in Drosophila and it recognizes specific structural motifs expressed by microbes which is essential for the establishment of the dorso-ventral pattern in developing embryos (Hashimoto $\mathrm{C}$ et al., 1988). The cornerstone of the innate immune system is composed of germline-encoded receptors which are known as patternrecognition receptors (PRRs), to which the Toll-like receptors belong (Takeda K et al., 2004).Upon recognition of "PathogenAssociated Molecular Patterns" or PAMPs, the TLRs are get activated. The cell surface Toll-like receptors (TLRs) recognize not only viral, bacterial, fungal and protozoan surface components, but also a plethora of endogenous molecules arising from host cell and tissue damage as well as the inflammatory response itself (Takeda K et al., 2004, Heil F et al., 2003, Gregory et al., 2003). TLRs recognize PAMPs that is enables the innate immune system to distinguish self from non-self and is important for triggering innate immunity against microbial infection and also for priming adaptive immune response. All TLRs activate MyD88-dependent pathways to induce a core set of stereotyped responses, such as inflammation. Individual TLRs can also induce immune responses that are tailored to a given microbial infection. Thus, these receptors are involved in both innate and adaptive immune responses. TLRs also detect endogenous molecules, such as damage- associated molecular patterns (DAMPS), which are produced by cells, in response to injury or infection (Prince LR et al., 2011). The study of Toll-like receptor (TLR) signalling pathways has proven to be a very fruitful area for investigators interested in signal transduction during innate immunity and inflammation (Akira S et al.,2011).

\section{Structure of toll like receptors}

TLRs are type 1 transmembrane proteins consist of an extracellular leucine-rich (LR) domain and a cytoplasmic tail that contains the resembles Toll/IL-1R gene homology (TIR) domain (Medzhitov R et al., 1997). The IL-1 receptors possess an Ig-like domain essential for signal transduction, whereas TLRs bear leucine-rich repeats (LRRs) in the extracellular domain involved in the ligand recognition (Medzhitov R et al., 1997). The proline residue in the TIR domains is present in all TLRs, except for TLR3, and its substitution leads to change in TLR signalling eg. Change in to histidine causes a dominant negative effect on TLRmediated signalling (Hoshino K et al., 1999, Underhill DM et al., 1999). To understand the molecular mechanism of TLRs it is necessary to know the molecular structures of the interfaces between proteins in signalling complexes and of the conformational changes that occur during signalling in TLRs (Lemaitre B 2004). 


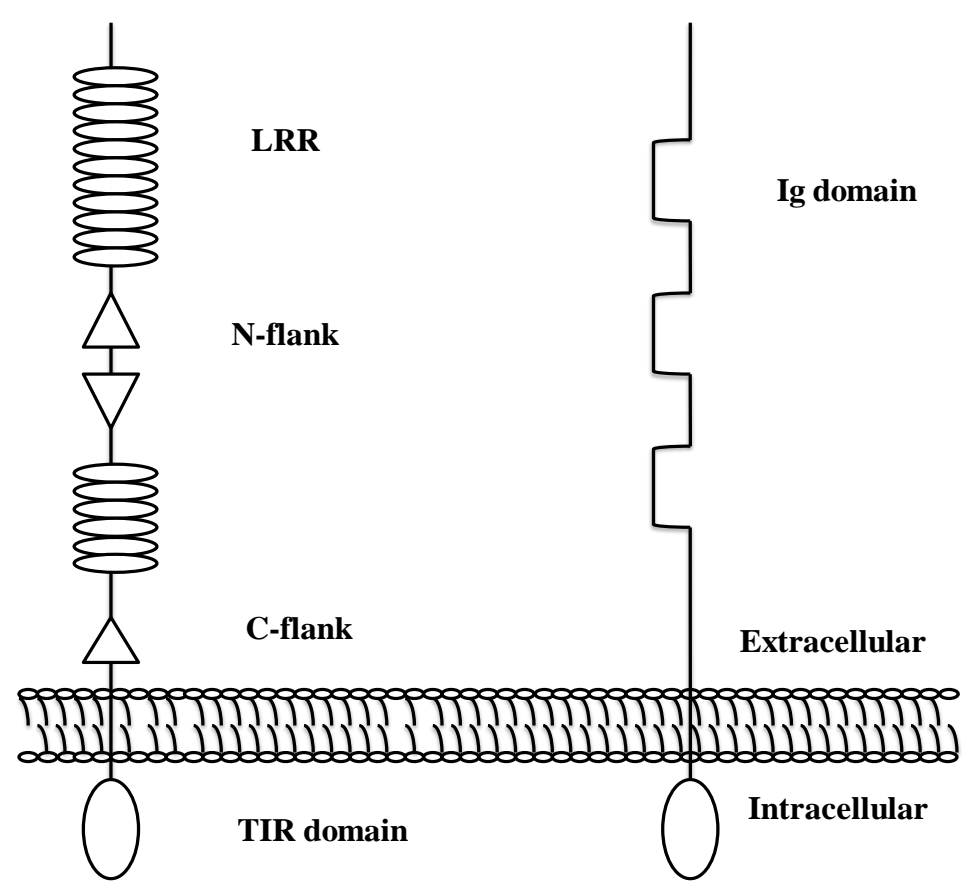

Fig. 1: Structure of Toll like Receptors (Lemaitre B 2004)

\subsection{Leucine rich-repeat regions}

The ectodomain of TLRs is responsible for recognization of ligands. The ectodomain structure provides a starting point for the understanding of its mode of signalling at the molecular level. The structure of the leucine rich repeat region is present at $2.3 \mathrm{~A}{ }^{\circ}$ in TLR (Li C et al., 2005, Khan JA et al., 2004). It is a large horseshoe-shaped solenoid, which is stabilized by asparagines conserved in each of the 23 leucine-rich repeat motifs that form hydrogen bonding networks. Eg. In TLR3 is heavily glycosylated apart from one face, which is glycosylation free and therefore contribute to homodimerization by creating a binding site for dsRNA. The binding of dsRNA might cause a conformational change in the dimer which would trigger changes in the disposition of the intracellular TIR domains to bring them closer for signal transduction.

\section{Toll like receptors and their ligands}

TLRs can be grouped into families according to the types of ligands they recognize. Recently 13 mammalian TLRs (10 in humans and 12 in mice) have been identified (Choe J et al., 2005). TLR10 is expressed in humans but not in mice; TLR11, TLR12 and TLR13 are expressed in mice but not in humans (Bell JK et al., 2005).With these TLRs the innate immune system discriminates different PAMPs from different microbial classes.

Human TLRs can be structurally divided into 5 subfamilies there is only 1 member in TLR3, TLR4 and TLR5 subfamilies; TLR2 subfamily consists of TLR1, TLR2, TLR6 and TLR10; and TLR9 subfamily consists of TLR7, TLR8 and TLR9 (Seki E \& Brenner 2008). TLR1/TLR2 and TLR2/TLR6 form heterodimers, and TLR4 and TLR9 form homodimerize. TLR1, TLR2, TLR4, TLR5 and TLR6 on cellular membrane mainly recognize bacterial products, which are not made by the host; so they can discriminate between self and non-self (Akira S \& Takeda K 2004). In contrast, TLR3, TLR7, TLR8 and TLR9 are localized to intracellular compartments, and specialize in the detection of viral nucleic acids, which are not unique to the pathogens. Nucleic acids cannot trigger the intracellular TLRs, but when the host derived nucleic acids become available for intracellular
TLRs as their corresponding ligands, they would break immune tolerance and lead to autoimmunity (Beutler B 2005 \& Schwabe RF 2006).

\section{Types of toll like receptors based on their cellular location}

The expression pattern of TLRs differs both inter-and intracellularly. Positive staining of the cell surface with antibodies to specific TLRs reveals that TLR1, TLR2, TLR4, TLR5 and TLR6 are all localized to the plasma membrane whereas TLR3, TLR7, TLR 8 and TLR9 are preferentially expressed in intracellular compartments such as endosomes. The nature of the ligand recognized by individual TLRs seems to determine their expression pattern. For example, TLR3, TLR7, TLR8 and TLR9 all recognize nucleic acid structures whereas TLR1, TLR2, TLR4, TLR5 and TLR6 generally recognize cell wall components. It should be noted however that surface exposed TLRs are not completely restricted in their expression pattern, for example, TLR2 can localize to phagosomes following exposure to certain ligands (Schwabe RF et al., 2006).

\subsection{Plasma membrane associated toll like receptors}

\subsubsection{TLR4}

The recognition of lipopolysaccharide (LPS) or endotoxin by TLR4 remains one of the most extensively studied aspects of TLR signalling. LPS acts through TLR4 come from studies on a strain of mice called the $\mathrm{C} 3 \mathrm{H} / \mathrm{HeJ}$ mice. These mice have a point mutation in the gene encoding TLR4 that renders them hyporesponsive to LPS challenge (Poltorak A et al., 1998, Rifkin IR et al., 2005, Takeda K \& Akira S 2005).TLR4 is also a receptor for endogenous ligands such as fibrinogen, heat shock proteins (HSP 60 and HSP 70), fibronectins and hyaluronic acid (Takeuchi $O$ et al., 2001). However, the doses at which these compounds were found to activate TLR4 far exceeded those required for the activation of TLR4 by LPS and it is also suspected that these preparations may have been contaminated with traces of LPS. 
Table 1: Toll like Receptors and Their Ligands

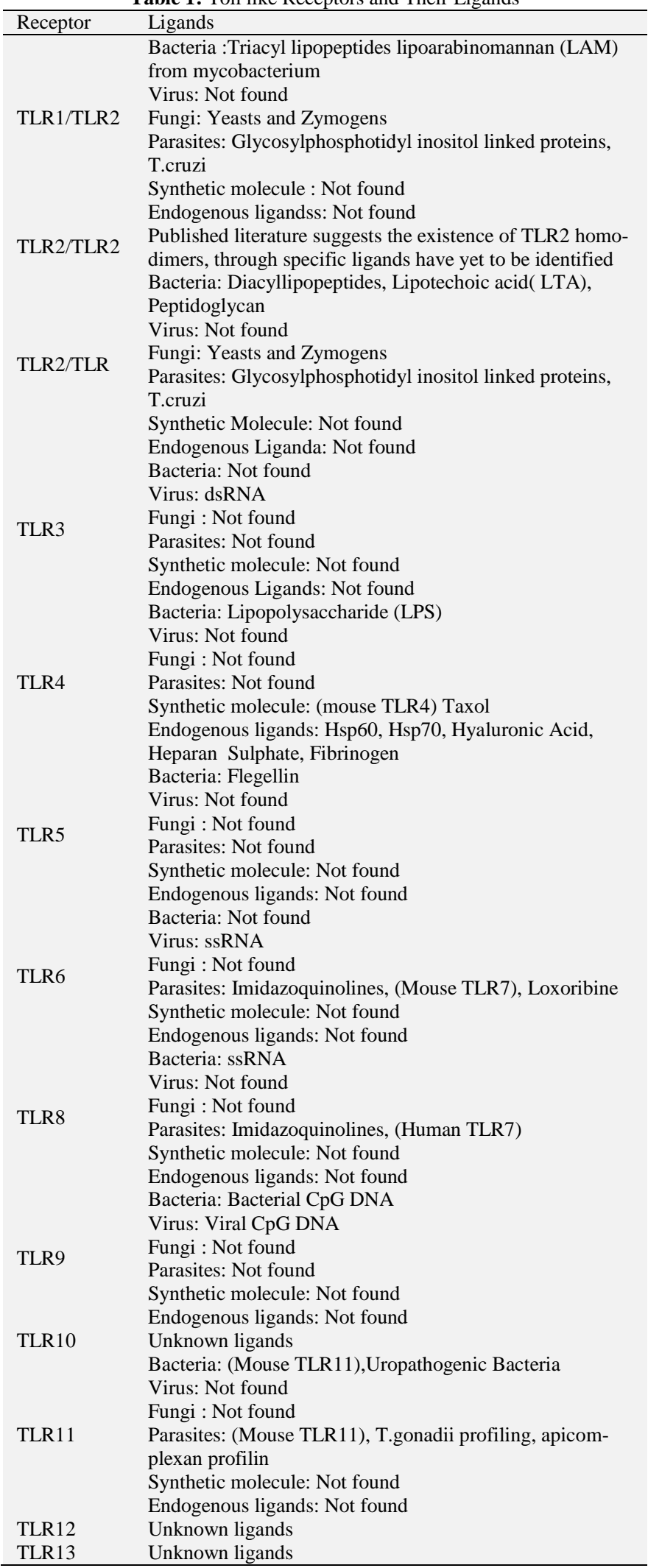

\subsubsection{TLR1, TLR2, TLR5 and TLR6}

TLR2 recognizes a vast array of microbial components including lipoproteins from various pathogens, peptidoglycan from gram positive bacteria, glycophosphatidylinositol (GPI) anchors from malaria causing parasites, zymosan from fungi and forms of LPS that are structurally distinct from those recognized by TLR4 (Takeuchi O et al., 2002). The ability of TLR2 to recognize such a wide range of compounds has been attributed to the ability of TLR2 to heterodimerize with other TLRs, namely TLR1 and TLR6. The association of TLR2 with TLR1 permits the recogni- tion of triacyl lipopeptides whereas TLR2/TLR6 heterodimers recognize diacyl lipopeptides (Alexopoulou L et al., 2001, Jurk M et al., 2002).

\subsection{Intracellular TLRs}

TLR3, TLR7 and TLR8 are nucleic acid recognizing TLRs in the context of viral infection whereas TLR9 is involved in the recognition of both bacterial and viral DNA (Hemmi, H et al., 2000, Lund J et al., 2003, Sen GC et al., 2005, Sarkar SN et al., 2003).TLR3 is highly expressed in macrophages, dendritic cells and epithelial cells (Sarkar, S.N et al., 2004) and induces the expression of IFN- $\beta$ following exposure to double stranded $(\mathrm{d} / \mathrm{s})$ RNA. TLRs 7 and 9 are expressed in a subset of DCs called plasmacytoid DCs or pre-DC2 cells. Exposure of these cells to ssRNA or DNA from viral genomes results in the secretion of large amounts of IFN- $\gamma$. These receptors also differ in their signaling profiles.

\subsubsection{TLR3}

TLR3 functions independently of MyD88 requiring only the adaptor TRIF to transmit signals to the nucleus whereas TLR7, TLR8 and TLR9 all signal via MyD88. TLR3 can activate NF-kB and this is thought to be mediated by the interaction of RIP1 with TRIF. The phosphorylation of TLR3 on Tyr759 facilitates the recruitment of PI3K. Mutation of this residue to phenylalanine not only prevented TLR3/PI3K complex formation but also resulted in only a partial phosphorylation of IRF3 and a failure to induce target genes. Phosphorylation on Tyr858 was also found to be critical for full IRF-3 activation. In a simplified scenario, phosphorylated TLR3 recruits both TRIF and PI3K (Kawai T et al., 2004).

\subsubsection{TLR7, TLR8, TLR9}

MyD88 and TRAF6 directly are directly associate with IRF7 to induce IFN- $\gamma$ following stimulation of cells with ligands for TLR7 and TLR9 (Uematsu et al., 2005). Silencing of the ubiquitinconjugating enzyme, UBC13, reduces the activation of IFN- $\gamma$ promoters indicating that the ubiquitin ligase activity of TRAF6 is required for the activation of IRF-7. It has been reported that IRAK-1 participates in the activation of IRF-7 possibly through direct phosphorylation as suggested by in vitro kinase assays (Hornef MW et al., 2004).

\section{Toll like receptors and its distribution}

Table 2: Toll like Receptor and Its Distribution (Hornef MW Et Al., 2003) Receptor Expression

\begin{tabular}{ll} 
TLR1 & Ubiquitous \\
TLR2 & Monocyte and Dendritic cells \\
TLR3 & Dendritic cells and NK cell \\
TLR4 & Macrophage,Dendritic and Endothelial cells \\
TLR5 & Monocyte, Immature dendriatic cells and NK cells \\
TLR6 & B cells, Monocytes and NK cells \\
TLR7 & B cells , Plasmacytoid precursor dendriatic cells \\
TLR8 & Monocytes, NK and T cells \\
TLR9 & Plasmacytoid precursor dendriatic cells, B cells, Macrophage, \\
TLR10 & Microglial cells \\
TLR11 & Not found \\
\hline
\end{tabular}

Distribution of TLRs within a particular tissue is vary in such a way that superficial epithelial cells, which are in constant contact with PAMPs having lack TLR expression whereas cells lining deeper areas of the tissue may express these receptors as they may be required to react to PAMP stimulation. For example, the epithelial cells of the intestinal crypt, which is normally a relatively sterile environment, express TLRs and are responsive to microbial PAMPs (Guillot L et al., 2003). TLR4 in crypt epithelial cells is expressed in the Golgi apparatus and it has been shown that LPS 
is internalized by these cells, trafficked to this organelle where it interacts with TLR4, which thereby initiates the signaling cascade downstream of this receptor (Backhed F et al., 2003). Similarly, TLR4 presents an intracellular localization in lung epithelia and plays a key role in response of pulmonary cells to Gram-negative bacteria derived ligands (Abreu MT et al., 2001).

\section{Toll like receptors signaling pathway}

The downstream cellular response of TLR activation involves the expression of numerous cytokines and chemokines as well as costimulatory molecules necessary for the activation of the immune response. Stimulation of distinct TLRs can give overlapping responses while in certain cases; a specific response appears to be attributed to a particular TLR.

On interaction with their ligands, TLRs mediate the activation of cell signalling cascades that ultimately result in the induction of the immune response and clearance of the infection from the host. Engagement of these Type- 1 transmembrane receptors with their respective foreign agonist induces dimerization, bringing together two signaling domains which subsequently serve as a platform for the recruitment of various intracellular adaptor molecules (Luke AJ \& O'Neill 2003, Xinyan LI 2009).

After ligand binding, the cytoplasmic TIR domain of TLRs activates downstream signaling via intracellular adapters. Five adapter proteins have been discovered, including myeloid differentiation primary response protein 88 (MyD88), Toll/IL-1 receptor domaincontaining adapter protein (TIRAP) (MyD88-adaptor-like, also called Mal), Toll/IL-1 receptor domain-containing adapter protein inducing IFN- $\beta$ (TRIF) (also known as TICAM1), TRIF-related adapter molecule (TRAM) (also known as TICAM2), and sterile $\alpha$ - and armadillo-motif containing protein (SARM). SARM functions as a specific inhibitor of TRIF-dependent pathway.


Fig. 2: Toll Like Receptor Signaling (X LI Et Al., 2010)

MyD88 is required for signaling by all TLRs except TLR3. TRIAP is a placement of TLR4 and TLR2 adaptor for mediation of MyD88-independent signaling. TRIF is the adaptor for TLR4 and TLR3 in the MyD88-independent pathway. TRAM functions 'upstream' of TRIF. The downstream signalling molecules include the transcription factors $\mathrm{NF}-\kappa \mathrm{B}$, mitogen-activated protein kinases (MAPKs), interferon regulatory factor-1 (IRF-1) and IRF-7, which lead to the activation of type I IFNs, proinflammatory cytokines or co stimulatory molecules.

Recent accumulating evidence indicates that TLR signaling pathways consist, at least, of a MyD88-dependent pathway that is common to all TLRs, and a MyD88-independent pathway that is peculiar to the TLR3- and TLR4 signaling pathways. 


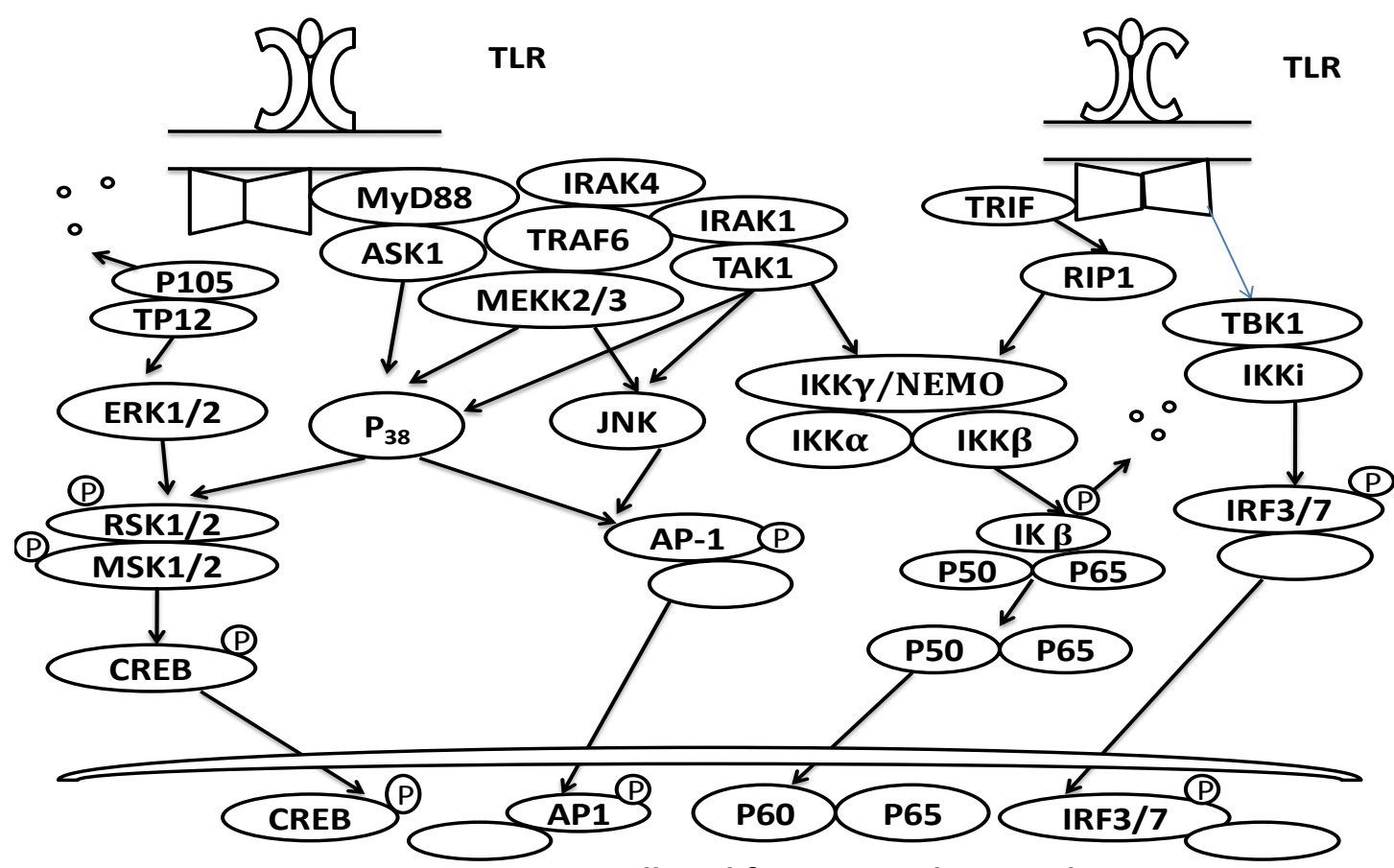

Immune Response cell proliferation and survival

Fig. 3: Adaptor Protein Involved in Signaling Pathway (Takeuchi O Et Al., 2000)

\subsection{MyD88-dependent pathway}

The adaptor proteins involved in MyD88 pathway are as follows:

\subsubsection{MyD88}

MyD88 possesses the TIR domain in the C-terminal portion, and a death domain in the N-terminal portion. MyD88 associates with the TIR domain of TLRs. Upon stimulation, (Fig-3) MyD88 recruits IL-1 receptor-associated kinase (IRAK) to TLRs through interaction of the death domains of both molecules. IRAK is activated by phosphorylation and then associates with TRAF6, leading to the activation of two distinct signaling pathways, and finally to the activation of JNK and NFkB.

Four new insights into MyD88 have been made, which has important role in inflammation and host defence.MyD88 knockout mice has showed no responses to the TLR4 ligand LPS in terms of macrophage production of inflammatory mediators, B cell proliferation, or endotoxin shock (Takeuchi O et al., 2000). The cellular responses to the TLR2 ligands peptidoglycan and lipoproteins were abolished in MyD88 knockout mice (Hacker H et al., 2000, Schnare M et al., 2000). Cells from MyD88 knockout mice showed no responses to the TLR9 ligand CpG DNA and the TLR7 ligand imidazoquinoline (Hemmi $\mathrm{H}$ et al., 2000, Hayashi $\mathrm{F}$ et al., 2001, Burns K et al., 2003). MyD88 knockout mice did not produce any IL-6 in response to the TLR5 ligand flagellin (Cao Z et al., 1996). These findings demonstrated that the TIR domaincontaining adaptor MyD88 is essential for the inflammatory responses mediated by all the TLR family members. MyD88s, which lacks the intermediate domain, has been shown to be induced by LPS stimulation and to inhibit LPS-induced NF- $\kappa B$ activation through inhibition of IRAK activity (Janssens S \& Beyaert R 2003, Swantek JL et al., 2000).Thus, MyD88s may negatively regulate the inflammatory responses triggered by LPS.

\subsubsection{IRAK}

IRAK was identified as a serine/threonine kinase associated with the IL-1 receptor. Four members of the IRAK family have been identified these are: IRAK-1, IRAK-2, IRAK-M, and IRAK-4 IRAK proteins consist of an $\mathrm{N}$-terminal death domain, which is responsible for interaction with MyD88, and a central kinase domain. IRAK-1 and IRAK-4 consist of Aspartate residue in the kinase domain, but this residue is not conserved in IRAK-2 or IRAK-M, which causes them to be catalytically inactive (Suzuki $\mathrm{N}$ et al., 2002). The importance of the IRAK family members in TLR-mediated signaling pathways was first demonstrated in IRAK-1 knockout mice (Li S et al., 2002). A biochemical study shown that IRAK-4 acts upstream of, and phosphorylates, IRAK-1 upon stimulation (Kobayashi $\mathrm{K}$ et al., 2002). Thus IRAK-4 is a central mediator of TLR signalling by activating IRAK-1.

\subsubsection{TRAF6 and downstream molecules}

TRAF6 is a member of the tumor necrosis factor receptor (TNFR)-associated factor (TRAF) family that mediates cytokine signaling pathways (Arch RH, Gedrich RW, Thompson CB 1998). TRAF proteins consist of two C-terminal TRAF domains (TRAF$\mathrm{N}$ and TRAF-C), which are responsible for interaction with TRAF proteins and other signaling molecules, $\mathrm{N}$-terminal RING finger, and zinc finger domains. Among the TRAF family members, TRAF6 has been shown to be involved in the TLR signalling pathway in addition to signaling pathways via the OPGL receptor and CD40 (Lomaga MA 1999, Naito A et al., 1999). Upon stimulation of TLRs, TRAF6 is recruited to the receptor complex, and activated by IRAK-1 that binds to the TRAF domain of TRAF6. Then, the IRAK-1/TRAF6 complex dissociates from the receptor and associates with TGF activated kinase 1 (TAK1) and TAK1binding proteins, TAB1 and $\mathrm{TAB} 2$, at the membrane portion. IRAK-1 stays in the membrane and is degraded, whereas the complex of TRAF6, TAK1, TAB1, and TAB2 moves into the cytoplasm, where it forms a large complex with other proteins, such as the E2 ligases Ubc13 and Uev1A (Deng L et al., 2000). The Ubc13 and Uev1A complex has been shown to catalyze the synthesis of a Lys 63-linked polyubiquitin chain of TRAF6 and thereby induce TRAF6-mediated activation of TAK1 and finally of NF-kB (Wang C et al., 2001).

\subsubsection{Other molecules}

Several other molecules have been implicated in the TLRmediated signaling pathway. Toll-interacting protein (Tollip) was first identified in an analysis of IL-1 signaling (Burns $\mathrm{K}$ et al., 2000). Tollip is present in a complex with IRAK-1. Upon stimulation with IL-1, the Tollip-IRAK-1 complex is recruited to the IL-1 receptor complex. IRAK-1 is then phosphorylated, which leads to the rapid dissociation of IRAK-1 from Tollip, thereby inducing 
activation of TRAF6. Subsequently, Tollip has been shown to negatively regulate the TLR-mediated signaling pathway (Bulut Y et al., 2002, Zhang G \& Ghosh S et al., 2002). Overexpression of Tollip inhibited activation of NF- $\mathrm{BB}$ in response to IL-1, the TLR2 and TLR4 ligands. Pellino was originally identified in Drosophila as a molecule that associates with Pelle, a Drosophila homologue of IRAK. In mammals, two Pellino homologues, Pellino-1 and Pellino-2, have been identified. Both Pellino-1 and Pellino-2 have been shown to interact with IRAK-1 in response to IL-1 stimulation (Takeda K \& Akira S 2004, Kawai T et al., 2001). Ectopic expression of the Pellino-2 antisense construct inhibited IL-1- or LPS-induced activation of the NF-kB-dependent promoter, indicating that Pellino-2 is involved in the IL- 1 and TLR4 signaling pathways.

\subsection{MyD88-independent pathway}

In the MyD88-independent pathway, LPS stimulation leads to activation of the transcription factor IRF-3, and thereby induces IFN- $\alpha$ IFN-Y, in turn, activates Stat1, leading to the induction of several IFN-inducible genes (Doyle SE et al., 2002, Toshchakov V et al., 2002, Hoshino K et al.,2002). In addition to the TLR4 ligand, the TLR3 ligand dsRNA has been shown to induce activation of NF-kB in MyD88 knockout cells (Alexopoulou L et al., 2001) Virus and viral-derived dsRNA are potent activators of IRF-3, which leads to the initial phase of IFN- $\alpha$ induction (Yu KY et al., 2002, Jiang $Z$ et al., 2003, Weaver BK, Kumar KP, Reich NC 1998). Thus, the TLR3 ligand dsRNA also activates the MyD88independent signaling pathway.

Two independent groups identified kinases responsible for the activation of IRF-3. IRF-3 was associated with IkB kinases (IKKs) (Yoneyama $\mathrm{M}$ et al., 1998). IKKs are composed of IKK- $\alpha$ and IKK $\beta$, both of which phosphorylate Ser32 and Ser36 of IkB, thereby inducing NF-kB activation. Two noncanonical IKKs, TANK-binding kinase 1 (TBK1) and IKK $\varepsilon / \mathrm{IKK} i$, which have distinct kinase activities compared with the canonical IKK $\beta$ and IKK $\alpha$.

RNAi-mediated ablation of TBK1 and IKK $/$ /KK $i$ resulted in inhibition of virus-induced phosphorylation of IRF-3. Overexpression of TBK 1 and IKKe/IKKi led to activation of IRF-3 and induction of IFN- $\beta$ (Sato $M$ et al., 2000). And reduced expression of TBK1 and IKK $\varepsilon /$ IKKi by RNAi led to impaired induction of IFN$\beta$ in response to virus and dsRNA. Thus, TBK1 and IKKe/IKKi have been shown to be critical regulators of IRF-3 activation, leading to the induction of IFN-Y in response to the TLR3 ligand.

\section{TIR domain-containing adaptors}

TLR signaling is mediated by an intracellular Toll/IL-1 receptor (TIR) domain, so named because it shares homology with that of IL- 1 receptor (Sharma $S$ et al., 2003).Two TIR domain-containing adaptors, TIR domain-containing adaptor protein (TIRAP)/MyD88-adaptor-like (Mal) and TIR domain-containing adaptor inducing IFN-Y (TRIF)/TIR domain-containing adaptor molecule (TICAM-1), were identified (Fitzgerald KA et al., 2003, Bonnard M et al., 2000 \& Horng T et al., 2001). Analysis of these two adaptors indicated that TIR domain-containing adaptors regulate the TLR-mediated signaling pathways.

\subsection{TIRAP/Mal}

Database search analyses led to the identification of TIR domaincontaining molecule, which was named TIRAP or Mal (Fitzgerald KA et al., 2001 \& Yamamoto $M$ et al., 2002). TIRAP/Mal consists of TIR domain in the C-terminus. MyD88 knockout macrophages, TIRAP/Mal knockout macrophages showed impaired inflammatory cytokine production and delayed activation of JNK and NF-kB in response to the TLR4 ligand. However, TLR4 ligand-induced activation of IRF-3 and expression of IFN- $\gamma$ inducible genes was normally observed in TIRAP/Mal knockout macrophages.
TIRAP/Mal is critically involved in the MyD88-dependent pathway, but not in the MyD88-independent pathway, via TLR4. TIRAP/Mal knockout mice showed normal responses to the TLR3, TLR5, TLR7, and TLR9 ligands, but were defective in TLR2 ligands-induced inflammatory cytokine production. TIRAP/Mal is essential for the MyD88-dependent signalling pathway via TLR2 and TLR4, but not for MyD88-independent signalling.

\subsection{TRIF}

TRIF/TICAM-1 was identified by a database search and as a TLR3-associated molecule by two-hybrid screening (Oshiumi H et al., 2003 \& Horng T et al., 2002).Unlike MyD88 and TIRAP/Mal, TRIF is a large protein consisting of 712 amino acids in humans. Over expression of TRIF as well as MyD88 and TIRAP caused activation of the NF-kB dependent promoter in 293 cells. Over expression of TRIF, but not MyD88 or TIRAP, induced activation of the IFN- $\beta$ promoter. Dominant negative TRIF inhibited the TLR3 ligand-induced activation of the IFN- $\beta$ promoter, and RNAi-mediated knockdown of TRIF caused impairment in the TLR3 ligand-induced IFN- $\beta$ expression. In TRIF knockout mice, TLR3-mediated expression of IFN- $\beta$ and IFN- $\gamma$ inducible genes was impaired (Yamamoto $M$ et al., 2002). TRIF knockout mice displayed defective expression of IFN- $\gamma$ inducible genes in response to the TLR4 ligand. A study of random germline mutagenesis in mice, using the alkylating agent $\mathrm{N}$-ethyl-N-nitrosourea (ENU), also revealed that TRIF-mutant mice were defective in the TLR3- and TLR4- mediated responses (Yamamoto $M$ et al., 2003). Thus, TRIF has been demonstrated to be essential for the TLR3- and TLR4-mediated MyD88 independent pathway. These studies clearly established that TIR domain-containing adaptors provide specificity for individual TLR-mediated signaling pathways. In addition to the impaired MyD88 independent pathway, TRIF knockout mice displayed defective TLR4-mediated inflammatory cytokine production, although activation of the MyD88dependent pathway, such as IRAK-1 phosphorylation and early phase of NF-kB activation, was not impaired. Therefore, the TLR4 signaling pathway is likely to require activation of both the MyD88-dependent and -independent pathways to induce inflammatory cytokines.

\subsection{SARM}

SARM (sterile and Heat-armadillo motifs) was the last TIR containing adaptor protein. SARM was originally identified as an orthologue of a Drosophila protein CG7915 (Belinda LW et al., 2008) and is evolutionarily conserved with orthologues of the protein described in zebra fish (O'Neill LA et al., 2003), Caenorhabditis elegans and the horseshoe crab. Recently the horseshoe crab orthologue of SARM (CrSARM) was characterized. As in humans, CrSARM was found to down regulate TRIF dependent TLR signalling in response to infection (Liberati NT et al., 2004). CrSARM was up regulated within $3 \mathrm{~h}$ of infection and strongly repressed at $6 \mathrm{~h}$ coinciding with the timing of bacterial clearance. This study suggests that the TRIF specific negative regulating role of SARM is evolutionary conserved from horseshoe crab to human (Kim Y et al., 2002).

SARM is a 690 a protein, which contains two sterile a motifs (SAMs) domains, a C-terminal TIR domain and N-terminal heat Armadillo repeat motif (ARM) (Kim Y et al., 2002). Of the TLR adaptors, SARM is the least well characterized. A, study of the C. elegans SARM homologue, TIR1 showed it to be important in the efficient immune response against infections, with knockdown of TIR1 by RNA interference resulting in decreased worm survival in response to fungal and bacterial infection (Persing DH et al., $2002 \&$, Ohashi $\mathrm{K}$ et al., 2000). A study by Carty et al., found that human SARM was a negative regulator of TRIF-dependent TLR signalling. They found that expression of SARM blocked gene induction downstream of TRIF but not MyD88 and knockdown of endogenous SARM led to enhanced TRIF-dependent cytokine 
production (Okamura Y et al., 2001). Interaction with SARM is preventing TRIF interacting with upstream or downstream signalling molecules. They found that SARM is primarily expressed in neurons where it associates with mitochondria, microtubules and JNK3 and regulates neuronal death during deprivation of oxygen and glucose (Frantz S et al., 1999) human and mouse myeloid cells expressed little SARM .

\section{Targeting toll like receptors}

Evidence is emerging that certain TLRs play a role in the pathogenesis of infectious and/or inflammatory diseases. The most studied TLRs in this regard are TLR4, anti-viral TLRs like TLR3 and TLR9.

\subsection{TLR4}

TLR4 is probably the key driver of tumor necrosis factor (TNF) during sepsis. During infection, conditions such as chronic obstructive pulmonary disease and asthma are exacerbated, and it is possible that TLRs drive the inflammation that gives rise to worsening symptoms. Blocking TLR4 (or indeed TLR2 or TLR5) might therefore be of use in the prevention of exacerbations. Finally, agonistic lipid a analogues are also being tested as adjutants, largely in the context of anti-tumor immunotherapy (Frantz S et al., 1999).

TLR4 has also been shown to be a possible receptor for endogenous factors released during tissue injury and inflammation, such as hsp60 (Alexopoulou et al., 2001) and fibronectin fragments (Alexopoulou et al., 2001 \& Hemmi $\mathrm{H}$ et al., 2002). In noninfectious inflammation, TLR4 might sense such products and provoke TNF production. TLR4 is expressed in the heart, especially during ischemia (Jurk M et al., 2002), and either in response to microbial products or endogenous factors might provoke inflammation and promote heart disease.

\subsection{TLR3}

A 'proof-of-principal' that inhibition of anti-viral TLRs is not only possible but also useful has come from a study with Vaccinia virus (VV). VV is a pox-virus containing several genes that encode decoys to block host defences but are not required for replication. It contains two proteins that appear to block TLR signalling, A46R and A52R (Frantz S et al., 1999 \& Alexopoulou L et al., 2001). A52R is similar to A46R, but acts to disrupt the downstream signalling components IL-1 receptor-associated kinase (IRAK)-2 and TNF receptor-associated factor-6 (TRAF-6). A52R is a potent inhibitor of TLR3 signalling, which is consistent with the role of TLR3 in anti-viral host defence. Importantly, a version of VV lacking A52R is attenuated in terms of causing illness during infection compared with wild-type virus, indicating that the virus uses $\mathrm{A} 52 \mathrm{R}$ to limit the host defence against itself (Alexopoulou L et al., 2001). This implies that it might be possible to develop inhibitors based on these viral proteins to limit TLR signalling.

TLR3 has been identified as an important receptor for polyI:C, a mimic of viral double-stranded RNA (Syed TA 2001).Stimulating TLR3 would be predicted to have anti-viral adjuvant effects, whereas blocking TLR3 might be useful in limiting viral virulence.TLR7andTLR8 appear to be receptors for a family of antiviral compounds based on imidazo quinolenes that are potent inducers of type I interferon (Bowie A et al., 2000 \& Harte MT et al., 2003). These compounds are currently in trial for genital herpes (Leadbetter EA et al., 2002).

\subsection{TLR9}

TLR9 is the receptor for CpG motifs, which occur in both bacterial and viral DNA. Apart from having potential as a target for adjuvants, a recent study suggests that TLR9 might have a role in autoantibody production (Alexopoulou L et al., 2001). In a mouse model of systemic lupus erythromatosus, it was demonstrated that immune complexes containing self DNA activate self-IgG-specific $\mathrm{B}$ cells as a result of co-stimulation of these B cells through TLR9 and the $\mathrm{B}$ cell receptor. This raises the intriguing possibility that TLRs, by sensing the products of damaged tissues, might provide the stimulus that gives rise to auto reactive B cell proliferation and autoantibody production. TLR9 could be a useful therapeutic target for both autoimmunity and asthma.

\section{References}

[1] Abreu MT, Vora P, Faure E, Thomas LS, Arnold ET, Arditi M. (2001) Decreased expression of Toll-like receptor-4 and MD-2 correlates with intestinal epithelial cell protection against dysregulated proinflammatory gene expression in response to bacterial lipopolysaccharide. J Immunol; 167:1609-1616.

[2] Akira S, Takeda K. (2004).Toll-like receptor signalling. Nat Rev Immunol; 4: 499-511.

[3] Akira S, Yamamoto M, Takeda K. (2003) Role of adapters in Toll-like receptor signalling. Biochem Soc Trans; 31(3):637-42.

[4] Alexopoulou L, Holt AC, Medzhitov R, Flavell RA. (2001). Recognition of double-stranded RNA and activation of NF-kappaB by Tolllike receptor 3. Nature; 413: 732-738.

[5] Alexopoulou L, Holt AC, Medzhitov R, Flavell RA. (2001). Recognition of double-stranded RNA and activation of NF- $\kappa \mathrm{B}$ by Toll-like receptor 3. Nature; 413:732 8.

[6] Alexopoulou L, Holt AC, Medzhitov R, Flavell RA. (2001). Recognition of double stranded RNA and activation of NF-kappaB by Tolllike receptor 3. Nature; 413:732-738.

[7] Arch RH, Gedrich RW, Thompson CB. (1998). Tumor necrosis factor receptor-associated factors (TRAFs) - a family of adapter proteins that regulates life and death. Genes Dev; 12:2821-30.

[8] Backhed F, Rokbi B, Torstensson E, Zhao Y, Nilsson C, Seguin D, Normark S, Buchan AM, Richter-Dahlfors A. (2003). Gastric mucosal recognition of Helicobacter pylori is independent of Toll-like receptor 4. J Infect Dis187:829-836.

[9] Belinda LW, Wei WX, Hanh BT, Lei LX, Bow H, Ling DJ. (2008). SARM: a novel Toll-like receptor adaptor, is functionally conserved from arthropod to human. Mol Immunol; 45:1732-42.

[10]Bell JK, Botos I, Hall PR, Askins J, Shiloach J, Segal DM, Davies DR (2005). The molecular structure of the Toll-like receptor 3 ligand binding domain. Proc Natl Acad Sci; 102:10976-10980.

[11]Beutler B. (2005). The Toll-like receptors: analysis by forward genetic methods. Immunogenetics; 57:385-92..

[12]Bonnard M, Mirtsos C, Suzuki S, Graham K, Huang J, Ng M, et al. (2000). Deficiency of T2K leads to apoptotic liver degeneration and impaired NF-кB-dependent gene transcription. EMBO J; 19: 4976-85.

[13]Bowie A, Kiss-Toth E, Symons JA, Smith GL, Dower SK, O'Neill LA. (2000). A46R and A52R from vaccinia virus are antagonists of host IL-1 and toll-like receptor signalling. Proc Natl Acad Sci; 97:1016210167.

[14]Bulut Y, Faure E, Thomas L, Equils O, Arditi M. (2002). Cooperation of Toll like receptor 2 and 6 for cellular activation by soluble tuberculosis factor and Borrelia burgdorferi outer surface protein a lipoprotein role of Toll-interacting protein and IL-1 receptor signaling molecules in Toll-like receptor 2 signalling. J Immunol; 167:987-94.

[15]Burns K, Clatworthy J, Martin L, Martinon F, Plumpton C, Maschera B, et al. (2000). Tollip, a new component of the IL-1RI pathway, links IRAK to the IL-1 receptor. Nat Cell Biol; 2:346-51..

[16]Burns K, Janssens S, Brissoni B, Olivos N, Beyaert R, Tschopp J. (2003). Inhibition of IL-1 receptor/Toll-like receptor signaling through the alternatively spliced, short form of MyD88 is due to its failure to recruit IRAK-4. J Exp Med; 197:263-8.

[17]Cao Z, Henzel WJ, GAO X. (1996). Irak: a kinase associated with the interleukin-1 receptor. Science; 271:1128-31.

[18]Choe J, Kelker MS, Wilson IA. (2005). Crystal structure of human toll like receptor 3 (TLR3) e ectodomain. Science; 309:581-585.

[19]Deng L, Wang C, Spencer E, Yang L, Braun A, You J, et al. (2000). Activation of the IÉ _ B kinase complex by TRAF6 requires a dimeric ubiquitin-conjugating enzyme complex and a unique polyubiquitin chain. Cell; 103:351-61.

[20]Doyle SE, Vaidya SA, O'Connell R, Dadgostar H, Dempsey PW, Wu T-T, et al. (2002). IRF3 mediates a TLR3/TLR4-specific antiviral gene program. Immunity; 7:251-63.

[21]Dunne A, Ejdeback M, Ludidi PL, O'Neill LA, Gay NJ. (2003). Structural complementarity of Toll/Interleukin1 receptor identity regions in 
toll-like receptors and the adaptors Mal and MyD88. J Biol Chem; 278:41443-41451.

[22] Fitzgerald KA, McWhirter SM, Faia KL, Rowe DC, Latz E, Golenbock DT et al. (2003). IKK $\varepsilon$ and TBK1 are essential components of the IRF3 signalling pathway. Nat Immunol; 4:491-6.

[23]Fitzgerald KA, Palsson-McDermott EM, Bowie AG, Jefferies C, Mansell AS, Brady G, et al. (2001). Mal (MyD88-adaptor-like) is required for Toll-like receptor-4 signal transduction. Nature; 413:78-83.

[24]Frantz S, Kobzik L, Kim YD, Fukazawa R, Medzhitov R, Lee RT, Kelly RA. (1999). Toll4 (TLR4) expression in cardiac myocytes in normal and failing myocardium. J Clin Invest; 104:271-280.

[25] Gregory M. Barton and Ruslan Medzhitov. (2003) Toll-Like Receptor Signalling Pathways. Nature immunology; 300:1524-1525.

[26]Guillot L, Medjane S, Le-Barillec K, Balloy V, Danel C, Chignard M, Si-Tahar M. (2003). Response of human pulmonary epithelial cells to LPS involves toll-like receptor 4(TLR4)-dependent signalling pathways: evidence for an intracellular compartmentalization of TLR4. J Biol Chem: in press.

[27]Hacker H, Vabulas RM, Takeuchi O, Hoshino K, Akira S, Wagner H. (2000). Immune cell activation by bacterial CpG-DNA through myeloid differentiation marker 88 and tumor necrosis factor receptorassociated factor (TRAF-6). J Exp Med; 192:595-600.

[28]Harte MT, Haga IR, Maloney G, Gray P, Reading PC, Bartlett NW, Smith GL, Bowie A, O'Neill LA. (2003). the poxvirus protein A52R targets Toll-like receptor signaling complexes to suppress host defense. J Exp Med; 197:343-35.

[29] Hashimoto C, Hudson KL, Anderson KV. (1988).The Toll gene of Drosophila, required for dorsal-ventral embryonic polarity, appears to encode a transmembrane protein. Cell; 52:269-79.

[30]Hayashi F, Smith KD, Ozinsky A, Hawn TR, Yi EC, Goodlett DR, et al. (2001). The innate immune response to bacterial flagellin is mediated by Toll-like receptor-5. Nature; 410:1099-103.

[31]Heil F, Ahmad-Nejad P, Hemmi H, Hochrein H, Ampenberger F, Gellert T et al. (2003) The Toll-like receptor 7 (TLR7)-specific stimulus loxoribine uncovers a strong relationship within the TLR7, 8 and 9 subfamily. Eur J Immunol; 33:2987-97.

[32]Hemmi H, Kaisho T, Takeuchi O, Sato S, Sanjo H, Hoshino K, Horiuchi T, Tomizawa H, Takeda K, Akira S. (2002). Small anti-vira compounds activate immune cells via the TLR7 MyD88- dependent signalling pathway. Nat Immunol; 3:196-200

[33]Hemmi H, Kaisho T, Takeuchi O, Sato S, Sanjo S, Hoshino K, et al. (2002). Small antiviral compounds activate immune cells via TLR7 MyD88-dependent signalling pathway. Nat Immunol; 3:196-200.

[34]Hemmi, H, Takeuchi O, Kawai T, Kaisho T, Sato S, Sanjo H, Matsumoto M, Hoshino K, Wagner H, Takeda K, Akira S.A. (2000). Tolllike receptor recognizes bacterial DNA. Nature; 408:740-745.

[35] Hornef MW, Frisan T, Vandewalle A, Normark S, Richter-Dahlfors (2004). a: toll-like receptor 4 resides in the Golgi apparatus and Cell surface receptors Host-microbe interactions: bacteria Current Opinion in Microbiology; 7:25-32.

[36]Hornef MW, Normark BH, Vandewalle A, Normark S: Intracellula recognition of lipopolysaccharide by toll-like receptor 4 in intestinal epithelial cells. J Exp Med. (2003): 198:1225-1235.

[37]Horng T, Barton GM, Flavell RA, Medzhitov R. (2002). The adaptor molecule TIRAP provides signalling specificity for Toll-like receptors. Nature; 420:329-33.

[38] Horng T, Barton GM, Medzhitov R. TIRAP: an adapter molecule in the Toll signaling pathway. Nat Immunol. (2001):2:835-41.

[39]Hoshino K, Kaisho T, Iwabe T, Takeuchi O, Akira S. (2002). Differential involvement of IFN- $\gamma$ in Toll-like receptor-stimulated dendritic cell activation. Int Immunol; 14:1225-31.

[40]Hoshino K, Takeuchi O, Kawai T, Sanjo H, Ogawa T, Takeda Y et al. (1999). Cutting edge: Toll-like receptor 4 (TLR4)-deficient mice are hyporesponsive to lipopolysaccharide: evidence for TLR4 as the Lps gene product. J Immunol; 162:3749-52.

[41]Janssens S, Beyaert R. (2003). Functional diversity and regulation of different interleukin-1 receptor-associated kinase (IRAK) family members. Mol Cell; 11:293-302.

[42]Jiang Z, Johnson HJ, Nie H, Qin J, Bird TA, Li X. (2003). Pellino 1 is required for interleukin-1 (IL-1)-mediated signalling through its interaction with the IL-1 receptor-associated kinase 4 (IRAK4) IRAKtumor necrosis factor receptor-associated factor 6 (TRAF6) complex. J Biol Chem; 278:10952-6.

[43]Jurk M, Heil F, Vollmer J, Schetter C, Krieg AM, Wagner H, Lipford G, Bauer S. (2002). Human TLR7 or TLR8 independently confer responsiveness to the antiviral compound R-848. Nat Immunol; 3:499.

[44]Jurk M., Heil F, Vollmer J, Schetter C, Krieg AM, Wagner H, Lipford G, Bauer S. (2002). Human TLR7 or TLR8 independently confer responsiveness to the antiviral compound R- 848. Nat. Immunol; 3:499.
[45] Kawai T, Sato S, Ishii KJ, Coban C, Hemmi H, Yamamoto M, Terai K, Matsuda M, Inoue J, Uematsu, S, Takeuchi O, Akira S. (2004). Interferon-alpha induction through Toll-like receptors involves a direct interaction of IRF7 with MyD88 and TRAF6. Nat. Immunol. (2004):5:1061-1068.

[46] Kawai T, Takeuchi O, Fujita T, Inoue J, Muhlradt PF, Sato S, et al. (2001). Lipopolysaccharide stimulates the MyD88-independent pathway and results in activation of IRF-3 and the expression of a subset of LPS-inducible genes. J Immunol; 167:5887-94.

[47] Khan JA, Brint EK, O'Neill LA, Tong L. (2004). Crystal structure of the Toll/interleukin-1 receptor domain of human IL-1RAPL. J Biol Chem; 279:31664-31670.

[48] Kim Y, Zhou P, Qian L, Chuang JZ, Lee J, Li C, et al. (2007) MyD88-5 links mitochondria, microtubules, and JNK3 in neurons and regulates neuronal survival. J Exp Med; 204:2063-74.

[49] Kobayashi K, Hernandez LD, Galan JE, Janeway Jr CA, Medzhitov R, Flavell RA. (2002). IRAK-M is a negative regulator of Toll-like receptor signaling. Cell; 110:191-202.

[50]Leadbetter EA, Rifkin IR, Hohlbaum AM, Beaudette BC, Shlomchik MJ, Marshak-Rothstein A. (2002). Chromatin-IgG complexes activate $\mathrm{B}$ cells by dual engagement of IgM and Toll-like receptors. Nature; 416:603-607.

[51]Lemaitre B. (2004).Toll like receptor:innate immune sensors. Nature review Immunol; 4(7):521-7.

[52]Li C, Zienkiewicz J, Hawiger J. (2005). Interactive sites in the MyD88 Toll/interleukin (IL) 1 receptor domain responsible for coupling to the IL1beta signaling pathway. J Biol Chem; 280:26152-26159.

[53]Li S, Strelow A, Fontana EJ, Wesche H. (2002). IRAK-4: a novel member of the IRAK family with the properties of an IRAK-kinase. Proc Natl Acad Sci; 99:5567-72.

[54]Liberati NT, Fitzgerald KA, Kim DH, Feinbaum R, Golenbock DT, Ausubel FM. (2004). Requirement for a conserved Toll/interleukin-1 resistance domain protein in the Caenorhabditis elegans immune response. Proc Natl Acad Sci; 101:6593-8.

[55]Lomaga MA, YehWC, Sarosi I, Duncan GS, Furlonger C, Ho A, et al. (1999). TRAF6 deficiency results in osteopetrosis and defective interleukin- 1, CD40, and LPS signaling. Genes Dev; 13:1015-24.

[56]Luke AJ, O'Neill. (2003). Theraputic targeting of Toll like receptor for inflammatory and infectious disease. Current opinion in pharmacology; 3:396-403.

[57]Lund J, Sato A, Akira S, Medzhitov R, Iwasaki. A. (2003). Toll-like receptor 9-mediated recognition of Herpes simplex virus-2 by plasmacytoid dendritic cells. J. Exp. Med; 198:513-520.

[58]Medzhitov R, Preston-Hurlburt P, Janeway Jr CA. (1997). A human homologue of the Drosophila Toll protein signals activation of adaptive immunity. Nature; 388:394-7.

[59]Naito A, Azuma S, Tanaka S, Miyazaki T, Takaki S, Takatsu K, et al. (1999). Severe osteopetrosis, defective interleukin-1 signalling and lymph node organogenesis in TRAF6-deficient mice. Genes Cells; 4:353-62.

[60]Ohashi K, Burkart V, Flohe S, Kolb H: Cutting edge: heat shock protein 60 is a putative endogenous ligand of the toll-like receptor- 4 complex. J Immunol. (2000): 164:558-561.

[61] Okamura Y, Watari M, Jerud ES, Young DW, Ishizaka ST, Rose J, Chow JC, Strauss JF III. (2001). the extra domain A of Fibronectin activates Toll-like receptor 4. J Biol Chem; 276:10229-10233.

[62]O'Neill LA, Fitzgerald KA, Bowie AG. (2003). The Toll-IL-1 receptor adaptor family grows to five members. Trends Immunol; 24:286-90.

[63] Oshiumi H, Matsumoto M, Funami K, Akazawa T, Seya T. (2003). TICAM-1 an adaptor molecule that participates in Toll-like receptor 3mediated interferon- $\alpha$ induction. Nat Immunol; 4:161-7.

[64]Persing DH, Coler RN, Lacy MJ, Johnson DA, Baldridge JR, Hershberg RM, Reed SG (2002). Taking toll: lipid a mimetics as adjuvants and immunomodulators. Trends Microbiol; 10:S32-S37.

[65]Poltorak A, He X, Smirnova I, Liu MY, Van Huffel C, Du X, Birdwell D, Alejos E, Silva M, Galanos C et al. (1998). Defective LPS signaling in $\mathrm{C} 3 \mathrm{H} / \mathrm{HeJ}$ and $\mathrm{C} 57 \mathrm{BL} / 10 \mathrm{ScCr}$ mice: mutations in $\mathrm{Tlr} 4$ gene. Science; 282:2085-2088.

[66]Poltorak A, Smirnova, I, Liu MY, Van Huffel C, Du X, Birdwell D, Alejos E, Silva M., Galanos C, Freudenberg M., Ricciardi-Castagnoli P, Layton B, Beutler, B. (1998) . Defective LPS signalling in $\mathrm{C} 3 \mathrm{H} / \mathrm{HeJ}$ and $\mathrm{C} 57 \mathrm{BL} / 10 \mathrm{ScCr}$ mice: mutations in Tlr4 gene. Science; 282:2085-2088.

[67]Prince LR, Whyte MK, Saboroe L, Parker LC. (2011). the role of Toll like receptors in neutrophil activation. Current opinion in pharmacology; 11:397-403.

[68]Rifkin IR., Leadbetter EA., Busconi L, Viglianti G, MarshakRothstein A. (2005). Toll-like receptors, endogenous ligands, and systemic autoimmune disease. Immunol. Rev; 204:27-42. 
[69]Sarkar SN, Smith HL, Rowe TM, Sen GC. (2003). Double-stranded RNA signalling by Toll-like receptor 3 requires specific tyrosine residues in its cytoplasmic domain. J. Biol. Chem; 278:4393-4396.

[70]Sarkar, S.N., Peters, K.L., Elco, C.P., Sakamoto, S., Pal, S. and Sen, G.C. (2004). Novel roles of TLR3 tyrosine phosphorylation and PI3 kinase in double-stranded RNA signalling. Nat. Struct. Mol. Biol; 11:1060-1067.

[71]Sato M, Suemori H, Hata N, Asagiri M, Ogasawara K, Nakao K, et al. (2000). Distinct and essential roles of transcription factors IRF-3 and IRF-7 in response to viruses for IFN- $\gamma$ gene induction. Immunity; 13:539-48.

[72]Schnare M, Holt AC, Takeda K, Akira S, Medzhitov R. (2000). Recognition of $\mathrm{CpG}$ DNA is mediated by signalling pathways dependent on the adaptor protein MyD88. Curr Biol; 10:1139-42.

[73]Schwabe RF, Seki E, Brenner DA. (2006). Toll-like receptor signalling in the liver. Gastroenterology; 130:1886-900.

[74]Seki E, Brenner DA. (2008). Toll-like receptors and adaptor molecules in liver disease: update. Hepatology; 48:322-35.

[75]Sen GC, Sarkar SN. (2005). Transcriptional signalling by doublestranded RNA: role of TLR3. Cytokine Growth Factor Rev; 16: 1-14.

[76] Sharma S, tenOever BR, Grandvaux N, Zhou GP, Lin R, Hiscott J. (2003). Triggering the interferon antiviral response through an IKKrelated pathway. Science; 300:1148-51.

[77]Suzuki N, Suzuki S, Duncan GS, Millar DG, Wada T, Mirtsos C, et al. Severe impairment of interleukin-1 and Toll-like receptor signalling in mice lacking IRAK-4. Nature. (2002):416:750-6.

[78] Swantek JL, Tsen MF, Cobb MH, Thomas JA. (2000). IL-1 receptor associated kinase modulates host responsiveness to endotoxin. J Immunol; 164:4301-6.

[79] Syed TA. (2001). a review of the applications of imiquimod: a novel immune response modifier. Expert Opin Pharmacother; 2:877-882..

[80]Takeda K, Akira S. (2004). TLR signaling pathways. Seminar in immunology; 16:3-9.

[81] Takeda K, Akira S. (2005). Toll-like receptors in innate immunity. Int. Immunol; 17:1-14.

[82]Takeda K., Akira S. (2004). Seminars in Immunology; 16: 3-99.

[83] Takeuchi O, Kaufmann A, Grote K, Kawai T, Hoshino K, Morr M, et al. (2000). Cutting edge: preferentially the R-stereoisomer of the Mycoplasmal lipopeptide macrophage-activating lipopeptide-2 activates immune cells through a Toll-like receptor 2- and MyD88dependent signalling pathway. J Immunol; 164:554-7.

[84] Takeuchi O, Kawai T, Muhlradt PF, Morr M, Radolf, JD, Zychlinsky A, Takeda K, Akira S. (2001). Discrimination of bacterial lipoproteins by Toll-like receptor 6 . Int. Immunol; 13:933-940.

[85] Takeuchi O, Sato S, Horiuchi T, Hoshino K, Takeda K, Dong Z, Modlin RL, Akira S. (2002). Cutting edge: role of Toll-like receptor 1 in mediating immune response to microbial lipoproteins. J. Immunol; 169:10-14.

[86]Takeuchi O, Takeda K, Hoshino K, Adachi O, Ogawa T, Akira S. (2000). Cellular responses to bacterial cell wall components are mediated through MyD88-dependent signalling cascades. Int Immunol; 12:113-7.

[87]Toshchakov V, Jones BW, Perera PY, Thomas K, Cody MJ, Zhang S, et al. (2002). TLR4, but not TLR2, mediates IFN- $\gamma$ induced STAT1 dependent gene expression in macrophages. Nat Immunol; 3: 392-8.

[88]Uematsu S, Sato S, Yamamoto M, Hirotani T, Kato H, Takeshita F, Matsuda M, Coban C, Ishii KJ, Kawai T, Takeuchi O, Akira S. (2005). Interleukin-1 receptor-associated kinase-1 plays an essential role for Toll-like receptor (TLR) 7- and TLR9-mediated interferon-\{alpha $\}$ induction. J. Exp. Med; 201:915-923.

[89]Underhill DM, Ozinsky A, Hajjar AM, Stevens A, Wilson CB, Bassetti $M$ et al. (1999). The Toll-like receptor 2 is recruited to macrophage phagosomes and discriminates between pathogens. Nature; 401:811-5.

[90]Wang C, Deng L, Hong M, Akkaraju GR, Inoue J-I, Chen ZJ. (2001). TAK1 is an ubiquitin-dependent kinase of MKK and IKK. Nature; 412:346-51.

[91]Weaver BK, Kumar KP, Reich NC. (1998). Interferon regulatory factor 3 and CREB-binding protein/p300 are subunits of doublestranded RNA activated transcription factor DRAF1. Mol Cell Biol 18:1359- 68

[92]X LI et al. (2010). Cytokine; 49:1-9.

[93]Xinyan LI, Song Jiang, Richard IT. (2010). Toll like receptor in cell proliferation and survival. Cytokine; 49(1)-1-9.

[94]Xu Y, Tao X, Shen B, Horng T, Medzhitov R, Manley JL, Tong L. (2000). Structural basis for signal transduction by the Toll/interleukin 1 receptor domains. Nature; 408:111-115.

[95] Yamamoto M, Sato S, Hemmi H, Hoshino K, Kaisho T, Sanjo H, et al. (2003). Role of adaptor TRIF in the MyD88-independent Toll-like receptor signaling pathway. Science. 301:640-3.
[96] Yamamoto M, Sato S, Hemmi H, Sanjo H, Uematsu S, Kaisho T, et al (2002). Essential role of TIRAP/Mal for activation of the signalling cascade shared by TLR2 and TLR4. Nature; 420:324-9.

[97] Yamamoto M, Sato S, Mori K, Hoshino K, Takeuchi O, Takeda K, et al. (2002). Cutting edge: a novel Toll/IL-1 receptor domain-containing adapter that preferentially activates the IFN- $\gamma$ promoter in the Tolllike receptor signaling. J Immunol; 169:6668-72

[98] Yoneyama M, Suhara W, Fukuhara Y, Fukuda M, Nishida E, Fujita T. (1998). Direct triggering of the type I interferon system by virus infection: activation of a transcription factor complex containing IRF-3 and CBP/p300. EMBO J; 17:1087-95.

[99] Yu KY, Kwon HJ, Norman DA, Vig E, Goebl MG, Harrington MA. (2002). Cutting edge: mouse Pellino-2 modulates IL-1 and lipopolysaccharide signalling. J Immunol; 169:4075-8.

[100] Zhang G, Ghosh S. (2002). Negative regulation of toll-like receptor-mediated signalling by Tollip. J Biol Chem; 77:7059-65. 